\title{
PENERAPAN PEMBELAJARAN KOOPERATIF MODEL JIGSAW DENGAN PENDEKATAN KONTEKSTUAL DALAM MENINGKATKAN MOTIVASI DAN HASIL BELAJAR PKN
}

\author{
Siti Hosniyah \\ SMA Negeri 2 Sampang \\ Email: siti-hosiyah@yahoo.com
}

\begin{abstract}
Abstrak:
Penelitian ini menggunakan model pembelajaran kooperatif jigsaw dengan pendekatan kontekstual karena dalam pembelajaran ini melibatkan kerjasama kelompok dan menuntut tanggung jawab serta menghubungkan pembelajaran dengan dunia nyata. Jenis penelitian ini adalah penelitian tindakan kelas (PTK) yang terdiri atas 2 siklus. Tiap siklus terdiri dari 4 tahapan yaitu perencanaan, pelaksanaan, observasi dan refleksi. Subjek yang digunakan dalam penelitian ini adalah siswa kelas X SMAN 2 Sampang dengan jumlah 39 siswa dalam materi pokok Kewenangan Lembaga-lembaga Negara Menurut UUD 1945. Penelitian ini bertujuan untuk 1) meningkatkan motivasi belajar siswa kelas X SMAN 2 Sampang. 2) meningkatkan hasil belajar siswa kelas kelas X SMAN 2 Sampang. Prosedur pengumpulan data meliputi: observasi keterlaksanaan pembelajaran, observasi motivasi belajar dan hasil belajar siswa diperoleh melalui pemberian tes yang dilaksanakan setiap akhir siklus. Analisis data yang digunakan adalah analisis deskriptif kualitatif. Hasil penelitian menunjukkan bahwa: 1) Motivasi belajar siswa mengalami peningkatan dari siklus I ke siklus II. Peningkatan motivasi belajar ini dikarenakan pembelajaran yang diterapkan memberikan tanggung jawab kepada siswa atas pembelajaran untuk dirinya dan orang lain, selain itu pembelajaran kooperatif memberikan kesempatan kepada siswa untuk berkolaborasi dengan anggota kelompok, sehingga siswa termotivasi untuk belajar.2) Hasil belajar siswa yang diukur dengan skor rata-rata dan persentase ketuntasan klasikal juga mengalami peningkatan dari siklus I ke siklus II. Peningkatan ini dikarenakan adanya interaksi promotif yang memungkinkan siswa saling memberikan motivasi untuk meraih hasil belajar yang optimal.
\end{abstract}

Kata Kunci: Jigsaw, pendekatan kontekstual, motivasi belajar, hasil belajar

\begin{abstract}
:
This study uses a jigsaw cooperative learning model with a contextual approach because in this study it involves group collaboration and demands responsibility and connects learning with the real world. This type of research is a classroom action research (PTK) consisting of 2 cycles. Each cycle consists of 4 stages: planning, execution, obser-vasi and reflection. The subjects used in this study are the students of class X SMAN 2 Sampang with the number of 39 students in the subject matter of the Authorities of State Institutions According to the 1945 Constitution. This study aims to 1 ) improve the motivation of students in grade $\mathrm{X}$
\end{abstract}


SMAN 2 Sampang. 2) improve student learning outcomes of grade X SMAN 2 Sampang. Data collection procedures include: observation of learning implementation, observation of learning motivation and student learning outcomes obtained through the provision of tests conducted at the end of each cycle. Data analysis used is qualitative descriptive analysis. The results showed that: 1) Student learning motivation increased from cycle I to cycle II. This increase in learning motivation is because the applied learning gives responsibility to the students for learning for themselves and others, besides cooperative learning gives opportunity to the students to collaborate with group members, so that students are motivated to learn. 2) Students' learning outcomes are measured by score average and the percentage of classical completeness also increased from cycle I to cycle II. This increase is due to the promotive interaction that allows students give each other motivation to achieve optimal learning outcomes

Keywords: Jigsaw, contextual approach, learning motivation, learning outcomes.

\section{Pendahuluan}

Upaya untuk meningkatkan sumber daya manusia salah satunya adalah dengan meningkatkan mutu pendidikan. Dalam rangka meningkatkan mutu pendidikan pemerintah berupaya meningkatkan kompetensi dalam kegiatan pembelajaran. Proses belajar mengajar merupakan inti dari kegiatan pendidikan di sekolah yang dikembangkan oleh guru, dengan pembelajaran yang tepat dan bermutu dapat menciptakan interaksi edukatif yang baik.

Agar mutu pendidikan di sekolah memiliki keunggulan kompetitif dan komparatif sesuai standar mutu nasional dan internasional, kurikulum perlu dikembangkan dengan Kurikulum Tingkat Satuan Pendidikan (KTSP). Hal ini tertuang dalam Undang-undang Republik Indonesia Nomor 20 tahun 2003 tentang sistem pendidikan nasional dan peraturan pemerintah Republik Indonesia nomor 19 tahun 2005 tentang standar nasional pendidikan yang mengamanatkan disusunnya KTSP jenjang pendidikan dasar dan menengah. KTSP adalah kurikulum operasional yang disusun dan dilaksanakan oleh masing-masing satuan pendidikan. Salah satu prinsip dikembangkannya KTSP adalah berpusat pada potensi, kebutuhan, perkembangan, dan kepentingan peserta didik juga lingkungannya. Tujuan pendidikan tingkat satuan pendidikan menengah adalah meningkatkan kecerdasaan, pengetahuan, kepribadian, akhlak mulia, serta keterampilan untuk hidup mandiri dan mengikuti pendidikan lebih lanjut. KTSP mampu mendukung kegiatan belajar mengajar di kelas lebih optimal. ${ }^{1}$

Proses pembelajaran dalam KTSP menuntut adanya partisipasi aktif dari seluruh siswa. Jadi kegiatan belajar berpusat pada siswa, guru sebagai motivator dan fasilitator di dalamnya agar suasana kelas lebih hidup. Pada suatu bentuk kegiatan pembelajaran yang baik kegiatan belajar yang dilakukan di sekolah selalu diarahkan pada tercapainya tujuan pembelajaran yang jelas yaitu pada pencapaian target pembelajaran yang telah ditetapkan dalam rencana pembelajaran. Target pembelajaran yang direncanakan tentunya adalah agar siswa dapat memahami

\footnotetext{
${ }^{1}$ Depdiknas, Kurikulum Tingkat Satuan Pendidikan, (Jakarta Depdiknas, 2003), 15.
} 
semua konsep yang diajarkan di sekolah, dengan kata lain memiliki pemahaman pa-da materi yang diajar. ${ }^{2}$

Salah satu masalah yang dihadapi dalam proses pembelajaran adalah siswa kurang termotivasi untuk mengembangkan kemampuan berpikir dan cenderung pasif karena guru berperan sebagai pusat pembelajaran. Proses pembelajaran di kelas mengarahkan anak untuk menghafal informasi begitu juga dengan model pembelajaran yang digunakan masih bersifat konvensional sehingga terkesan membosankan. Anak dipaksa untuk mengingat berbagai informasi tanpa dituntut memahami informasi yang diingatnya itu untuk menghubungkan dengan kehidupan sehari-hari. Akibatnya ketika anak didik lulus dari sekolah mereka pintar secara teoritis tetapi mereka tidak mampu dalam kehidupan sehari-hari. Pendidikan di sekolah terlalu membebani anak dengan berbagai bahan ajar yang harus dihafal. Pendidikan tidak diarahkan untuk mengembangkan dan membangun karakter serta potensi yang dimiliki. Proses pendidikan kita tidak diarahkan untuk membentuk manusia cerdas, memiliki kemampuan memecahkan masalah hidup, serta tidak diarahkan untuk membentuk manusia kreatif dan inovatif. ${ }^{3}$

Berdasarkan hasil belajar siswa sebelumnya pada mata pelajaran Pendidikan Kewarganegaraan (PKn) diperoleh data sebagai berikut: Jumlah siswa kelas X sebanyak 39 siswa yang tidak tuntas dalam mencapai KKM sebanyak 18 siswa dengan prosentase keberhasilan 46,15\%, siswa yang tuntas dalam mengikuti materi sebelumnya sebanyak 21 siswa dengan prosentase keberhasilan 53,85\%, Kriteria Ketuntasan Minimal ( KKM ) untuk SMA Negeri 2 Sampang Kabupaten Sampang untuk mata pelajaran PKn sebesar 70.

Untuk mengatasi permasalahan tersebut di atas upaya yang dapat dilakukan adalah dengan menerapkan model, metode dan teknik pembelajaran yang sesuai dengan standar kompetensi dan kompetensi dasar. Dengan penggunaan metode pembelajaran yang sesuai diharapkan dapat diperoleh hasil pembelajaran yang baik pula, yang nantinya akan berdampak terhadap proses belajar mengajar menjadi bermakna artinya dalam pembelajaran akan memberikan makna langsung terhadap perubahan tingkah laku peserta didik.

Hamzah B. Uno menyatakan bahwa metode pembelajaran adalah cara yang digunakan guru, yang dalam menjalankan fungsinya merupakan alat untuk mencapai tujuan pembelajaran. ${ }^{4}$

Mengingat materi pelajaran PKN dikelas X sebagian adalah materi regional maka agar tujuan pembelajaran dapat tercapai secara optimal memerlukan model dan metode yang tepat, salah satu model pembelajaran yang sesuai dan berorientasi pada siswa adalah pendekatan kontekstual yang dikenal dengan Contextual Teaching and Learning (CTL). Contextual Teaching Learning merupakan konsep belajar yang mendorong guru untuk menghubungkan materi yang diajarkan dan situasi dunia nyata siswa dan juga mendorong siswa membuat

\footnotetext{
2 Ibid, 18.

3 Muhibbin Syah, Psikologi Pendidikan dengan Pendekatan Baru. (Bandung: Rosda. 2007), 23.

${ }^{4}$ Hamzah B, Uno, Perencanaan Pembelajaran, (Jakarta: Bumi Aksara,2007), 2.
} 
hubungan antara pengetahuan yang dimilkinya dan penerapannya dalam kehidupan sahari-hari. ${ }^{5}$

Jigsaw merupakan salah satu model pembelajaran kooperatif yang memiliki ciri adanya kelompok asal dan kelompok ahli. Setiap orang dari kelompok ahli setelah diskusi kembali ke kelompok asal untuk menjelaskan hasil diskusi masingmasing siswa di kelompok ahli. Keunggulan model pembelajaran kooperatif jigsaw meningkatkan rasa tanggung jawab siswa terhadap pembelajarannya sendiri dan pembelajaran orang lain. Siswa tidak hanya mempelajari materi yang diberikan tetapi mereka juga harus siap memberikan dan mengajarkan materi tersebut pada anggota kelompoknya yang lain. Melalui proses pembelajaran semacam itu siswa diharapkan termotivasi untuk serius dalam diskusi kelompok ahli untuk menguasai materinya dan menyampaikannya dalam diskusi kelompok asal. Siswa juga serius dalam diskusi kelompok asal untuk dapat memahami setiap materi yang diperoleh oleh setiap anggota kelompok pada diskusi kelompok ahli. ${ }^{6}$

Penggabungan antara model pembelajaran kooperatif jigsaw dengan pendekatan kontekstual penting untuk dilakukan karena diharapkan siswa mampu menghubungkan ilmu pengetahuannya dengan kehidupan sehari-hari sehingga hal-hal yang diperoleh dalam belajar dapat diterapkan dalam kesehariaannya. Selain itu melalui pendekatan kontekstual siswa akan lebih mudah untuk mengingat apa yang ia pelajari sebab akan diaplikasikan secara langsung.

Berdasarkan latar belakang masalah penelitian dengan judul "Penerapan Model Pembelajaran Kooperatif Jigsaw dengan Pendekatan Kontekstual dalam Meningkatkan Motivasi dan Hasil Belajar PKn siswa kelas X SMA Negeri 2 Sampang Sampang tahun 2017/2018".

\section{Model Pembelajaran Kooperatif Jigsaw}

Salah satu model pembelajaran kooperatif adalah jigsaw. Pembelajaran kooperatif adalah pembelajaran yang secara sadar dan sengaja mengembangkan interaksi yang silih asah, silih asuh dan asih antar sesama siswa sebagai latihan hidup di dalam masyarakat nyata. ${ }^{7}$ Menurut Nurhadi Metode ini dikembangkan oleh ElliotAronson's dan kawan-kawannya dari dari Universitas Texas dan kemudian di adaptasi oleh Slavin dan kawan-kawannya melalui metode Jigsaw, kelas dibagi menjadi beberapa tim yang anggotanya terdiri 4-5 siswa dengan karakteristik yang hiterogen.

Jigsaw adalah model pembelajaran kooperatif yang dikembangkan oleh Elliot Aronson's. Model pembelajaran ini didesain untuk meningkatkan rasa tanggung jawab siswa terhadap pembelajarannya sendiri dan juga pembelajaran orang lain. Siswa tidak hanya mempelajari materi yang diberikan, tetapi mereka juga harus siap memberikan dan mengajarkan materi tersebut kepada kelompoknya. Sesuai dengan namanya, teknis penerapan tipe pembelajaran ini maju mundur seperti gergaji. Jigsaw dikembangkan oleh Aronson sebagai metode

\footnotetext{
${ }^{5}$ Nurhadi dkk,, Pembelajaran Kontekstual dan Penerapannya dalam KBK. (Malang: Universitas Negeri Malang. 2005), 103.

${ }^{6}$ Muhibbin Syah, Psikologi Belajar. Jakarta: PT Raja Grafindo, 2005), 46.

${ }^{7}$ Nurhadi dkk,, Pembelajaran Kontekstual dan Penerapannya dalam KBK. (Malang: Universitas Negeri Malang. 2004), 65.
} 
Cooperative Learning. Teknik ini dapat digunakan dalam pengajaran membaca, menulis, mendengarkan, ataupun berbicara. ${ }^{8}$

Dalam jigsaw, guru memperhatikan skemata atau latar belakang pengalaman siswa dan membantu siswa mengaktifkan skemata ini agar bahan pelajaran menjadi lebih bermakna. Selain itu, siswa bekerja sama dengan sesama siswa dalam suasana gotong royong dan mempunyai banyak kesempatan untuk mengolah informasi dan meningkatkan keterampilan berkomunikasi. Model pembelajaran kooperatif jigsaw adalah suatu model pembelajaran kooperatif yang terdiri dari beberapa anggota dalam satu kelompok yang bertanggung jawab atas penguasaan bagian materi belajar dan mampu mengajarkan materi tersebut kepada anggota lain dalam kelompoknya.

Para anggota dari tim-tim yang berbeda dengan topik yang sama bertemu untuk diskusi (tim ahli) saling membantu satu sama lain tentang topik pembelajaran yang ditugaskan kepada mereka. Kemudian siswa-siswa itu kembali pada tim atau kelompok asal untuk menjelaskan kepada anggota kelompok yang lain tentang apa yang telah mereka pelajari sebelumnya pada pertemuan tim ahli. Pada model pembelajaran kooperatif jigsaw, terdapat kelompok asal dan kelompok ahli. Kelompok asal yaitu kelompok induk siswa yang beranggotakan siswa dengan kemampuan, asal, dan latar belakang keluarga yang beragam. Kelompok asal merupakan gabungan dari beberapa ahli. Kelompok ahli yaitu kelompok siswa yang terdiri dari anggota kelompok asal yang berbeda yang ditugaskan untuk mempelajari dan mendalami topik tertentu dan menyelesaikan tugas yang berhubungan dengan topiknya untuk kemudian dijelaskan kepada anggota kelompok asal. ${ }^{9}$

Kunci pembelajaran ini adalah interpedensi setiap siswa terhadap anggota kelompok untuk memberikan informasi yang diperlukan dengan tujuan agar dapat mengerjakan tes dengan baik. Bila dibandingkan dengan metode pembelajaran tradisional, model pembelajaran Jigsaw memiliki beberapa kelebihan yaitu:

a. mempermudah pekerjaan guru dalam mengajar, karena sudah ada kelompok ahli yang bertugas menjelaskan materi kepada rekan-rekannya

b. pemerataan penguasaan materi dapat dicapai dalam waktu yang lebih singkat

c. metode pembelajaran ini dapat melatih siswa untuk lebih aktif dalam berbicara dan berpendapat.

\section{Pembelajaran Kontekstual}

Dewasa ini pembelajaran kontekstual telah berkembang di negara-negara maju dengan berbagai nama. Pembelajaran kontekstual adalah pengajaran yang memungkinkan siswa memperkuat, memperluas, dan menerapkan pengetahuan dan ketrampilan akademisnya dalam berbagai latar sekolah dan di luar sekolah untuk memecahkan seluruh persoalan yang ada dalam dunia nyata.

Pembelajaran kontekstual (Contextual Teaching and learning) adalah konsep belajar yang membantu guru mengaitkan antara materi yang diajarkannya de-ngan situasi dunia nyata siswa dan mendorong siswa membuat hubungan antara pengetahuan yang dimilikinya dengan penerapannya dalam kehidupan mereka sehari-hari, dengan melibatkan tujuh komponen utama pembelajaran

\footnotetext{
${ }^{8}$ A. Lie, Mempraktekkan Cooperative Learning. (Jakarta: Gramedia. 2007), 67.

${ }^{9}$ Ibid, 36.
} 
efektif, yak-ni: konstruktivisme (Constructivism), bertanya (Questioning), menemukan (Inqui-ri), masyarakat belajar (Learning Community), pemodelan (Modeling), dan penilaian sebenarnya (Authentic Assessment). ${ }^{10}$

Pembelajaran kontekstual terjadi ketika siswa menerapkan dan mengalami apa yang diajarkan dengan mengacu pada masalah-masalah riel yang berarosiasi dengan peranan dan tanggung jawab mereka sebagai anggota keluarga, anggota masyarakat, siswa dan selaku pekerja. Pengajaran dan pembelajaran kontekstual menekankan berpikir ilmu, mengumpulkan, menganalisis dan mensitesiskan informasi dan data dari berbagai sumber dan sudut pandang.

Pembelajaran kontekstual merupakan suatu proses pendidikan yang holistik dan bertujuan memotivasi siswa untuk memahami makna materi pelajaran yang dipelajarinya dengan mengkaitkan materi tersebut dengan konteks kehidupan mereka sehari-hari (konteks pribadi, sosial, dan kultural) sehingga siswa memiliki pengetahuan/keterampilan yang secara fleksibel dapat diterapkan (ditransfer) dari satu permasalahan/konteks ke permasalahan/konteks lainnya. Merupakan konsep belajar yang membantu guru mengkaitkan antara materi yang diajarkannya dengan situasi dunia nyata dan mendorong pembelajar membuat hubungan antara materi yang diajarkannya dengan penerapannya dalam kehidupan mereka sebagai anggota keluarga dan masyarakat. ${ }^{11}$

Pendekatan kontekstual mendasarkan diri pada kecenderungan pemikiran tentang belajar yaitu proses belajar, transfer belajar, siswa sebagai pembelajar, dan pentingnya lingkungan belajar. Adapun uraian dari beberapa point tersebut adalah.

1. Proses belajar

Slameto menyebutkan" Belajar adalah suatu proses usaha yang dilakukan seseorang untuk memperoleh suatu perubahan tingkah laku yang baru secara keseluruhan, sebagai hasil pengalamannya sendiri dalam interaksi dengan lingkungannya". ${ }^{12}$

2. Transfer Belajar

Slameto menyebutkan bahwa" mengajar adalah bimbingan kepada siswa dalam proses belajar dalam hal ini siswa yang aktif belajar, guru hanya membimbing, menunjukkan jalan dengan memperhatikan kepribadian siswa". ${ }^{13}$

3. Siswa sebagai Pembelajar

Keberhasilan seseorang dalam pembelajaran sesuai dengan kurikulum 2013 dapat dilihat dari kualitas pembelajaran berdasarkan pembentukan kompetensi. Keberhasilan pembelajaran dapat dilihat dari segi proses dan segi hasil. ${ }^{14}$

4. Pentingnya Lingkungan Belajar

Slameto menjelaskan faktor-faktor yang mempengaruhi belajar banyak jenisnya, tetapi dapat digolongkan menjadi dua golongan saja yaitu: Faktor Intern yang terdiri dari: (a) Faktor fisiologi, dan (b) Faktor Psikologi; dan Faktor

\footnotetext{
${ }^{10}$ Nurhadi dkk,, Pembelajaran Kontekstual dan Penerapannya dalam KBK. (Malang: Universitas Negeri Malang. 2004),78.

${ }^{11}$ Dimyati dan Mudjiono. Belajar dan Pembelajaran. (Jakarta: Rineka Cipta, 2006), 92.

${ }^{12}$ Slameto, Belajar dan Faktor-faktor yang Mempengaruhinya, (Jakarta: Rineka Cipta,2003), 2.

13 Ibid, 30

${ }^{14}$ E. Mulyasa, Praktik Penelitian Tindakan Kelas, (Bandung: Remaja Rosdakarya, 2006), 131.
} 
Eksternal yang terdiri dari: (a) Faktor keluarga, (b) Faktor sekolah, dan (c) Faktor masyarakat 15

Dalam pembelajaran/pendekatan kontekstual terdapat tujuh komponen utama. Berikut ini adalah uraian mengenai ketujuh komponen utama dalam pembelajaran kontekstual yang terdapat pada Contextual Teaching and Leaning sebagai berikut. ${ }^{16}$

1. Kontrukstivisme (Constructivism). Staregi dasar dari kontruktivisme adalah meaningful learning yaitu pembentukan pengetahuan melibatkan interpretasi kita atas peristiwa. Dengan kontruktivisme diharapkan dalam pembelajaran terjadi kebermaknaan. Pembelajaran ini berkaitan dengan pemahaman dan penilaian pribadi dan berkaitan dengan kepentingan siswa. Dalam pembelajaran ini sangat terkait dengan kehidupan yang nyata dan siswa menyadari bahwa belajar demi kehidupannya dimasa yang akan datang.

2. Menemukan (Inquiri). Metode ini berpusat pada kegiatan peserta didik, dengan cara memproses pengalaman belajar melalui kebermaknaan dalam kehidupan nyata. Endang Ekowati menyatakan komponen inquiri merupakan konsep dalam pembelajaran melewati suatu siklus (1) observasi atau mengamati; (2) bertanya; (3) mengajukan dugaan (hipotesi); (4) pengumpulan data; dan menyimpulkan. ${ }^{17}$

3. Bertanya (Questioning). Bertanya merupakan salah satu komponen keahlian dasar yang perlu dikembangkan oleh guru. Bertanyamerupakan salah satu alat pembelajaran untuk mendorong, membimbing dan menilai kemampuan berfikir siswa. Pertanyaan juga digunakan oleh siswa selama melaksanakan kegiatan yang berbasis penemuan. Nurhadi menyatakan pertanyaan dalam proses pembelajaran dapat dikelompokkan menjadi tiga (a) pertanyaan diskriptif yaitu pertanyaan dengan kata ganti apa; (b) pertanyaan eksplanatif yaitu pertanyaan yang mengarahkan kepada permintaan pada siswa untuk menjelaskan ( misal: jelaskan dan bagaimana proses terjadinya; (c) pertanyaan kritis dan kreatif, yaitu pertanyaan yang meminta kepada siswa untuk mengungkap informasi yang tersurat dan tersirat pada fakta dan informasi ( misal: beberapa pertanyaan yang menggunakan kata ganti tanya mengapa). Dalam aktivitas bertanya dapatdilakukan antara siswa dengan siswa ataupun antara siswa dengan guru ataupun dengan orang lain. ${ }^{18}$

4. Masyarakat Belajar (Learning Community). Konsep learning comunity ialah hasil pembelajaran yang diperoleh dari kerjasama dengan orang lain dalam learning comunity proses pembelajaran berlangsung dalam situasi kebersamaan, siswa saling berbagi pengalaman diantara mereka. Bekerjasama dengan orang lain untuk menciptakan pembelajaran siswa aktif lebih baik jika dibandingkan dengan belajar sendiri. Nurhadi mengatakan dalam masyarakat belajar atau learning community disarankan guru melaksanakan pembelajaran dalam kelompok-kelompok belajar, secara heterogen hal ini akan terjadi saling

\footnotetext{
${ }^{15}$ Slameto, Belajar \& Faktor-faktor yang Mempengaruhinya, (Jakarta: Rineka Cipta,2003), 54

${ }^{16}$ Nurhadi dkk,, Pembelajaran Kontekstual dan Penerapannya dalam KBK. (Malang: Universitas Negeri Malang. 2004), 77.

${ }^{17}$ Endang Ekowati, Penelitian Tindakan Kelas, (Malang P4TK, 2007), 18.

${ }^{18}$ Nurhadi dkk,, Pembelajaran Kontekstual dan Penerapannya dalam KBK. (Malang: Universitas Negeri Malang. 2004), 5.
} 
memberikan pengetahuan dan pengalamannya yang pandai akan mengajari yang lemah dan yang sudah tahu akan memberi tahu yang belum tahu. ${ }^{19}$

5. Pemodelan (Modeling). Model berarti contoh artinya tidak ada satu cara terbaik, tetapi ada beberapa cara terbaik. Tujuan yang akan dicapai dalam pemodelan adalah siswa untuk berkompetensi dengan teman-temannya sehingga dalam pembelajaran bersifat inovatif. Guru bukan merupakan salah satu model, tetapi model dapat dirancang dengan melibatkan siswa. ${ }^{20}$

6. Refleksi (reflection). Endang Ekowati menyatkan refleksi adalah cara berfikir tentang apa yang baru dipelajari atau berfikir kebelakang tentang apa yang sudah dilakukan dimasa lalu. Refleksi merupakan salah satu respon terhadap adanya kejadian, aktifitas atau pengetahuan yang baru diterima. Refleksi adalah cara berpikir apa yang baru dipelajari atau berpikir ke belakang tentang apa yang sudah kita lakukan dimasa yang lalu. Refleksi merupakan respon terhadap kejadian, aktivitas, atau pengetahuan yang baru diterima. Refleksi adalah berpikir kembali tentang materi yang baru dipelajari, merenungkan lagi aktivitas yang telah dilakukan atau mengevaluasi kembali bagaimana belajar yang telah dilakukan.

7. Penilaian yang Sebenarnya (Authentic Assesmen). Endang Ekowati menyatakan penilaian sebenarnya atau authentic Assesmen mempunyai karakteristik : (1) dilaksanakan selama dan sesudah proses pembelajaran; (2) bisa digunakan untuk formatif maupun sumatif; (3) yang diukur keterampilan dan performansi, bukan mengingat fakta; (4) berkesinambungan; terintegrasi dan (6) dapatdipergunakan sebagai umpan balik atau feed back. ${ }^{21}$

Menurut Suherman model pembelajaran yang bisa diterapkan dalam pembelajaran konstektual diantaranya adalah: (a) pembelajaran langsung (direct instruction); (b) pembelajaran kooperatif (cooperatif learning); (c) pembelajaran berbasis masalah (problem based instruksional); (d) pembelajaran problem terbuka (open ended); dan (e) model savi (somatic, auditory, visuality, intellectuality)..$^{22}$

\section{Hasil Belajar Peserta Didik}

Di dalam istilah hasil belajar, terdapat dua unsure didalamnya yaitu unsure hasil dan unsur belajar. Hasil merupakan suatu hasil yang telah dicapai pebelajar dalam kegiatan belajarnya (dari yang telah dilakukan, dikerjakan, dan sebagainya), sebagaimana dijelaskan dalam kamus besar bahasa Indonesia. Dari pengertian ini maka hasil belajar adalah penguasaan pengetahuan atau ketreampilan yang dikembangkan oleh mata pelajaran, lazimnya ditunjukkan dengan nilai tes atau angka nilai yang diberikan oleh guru.

Menurut Winarno Surahman, "Hasil belajar adalah hasil dimana guru melihat bentuk akhir dari pengalaman interaksi edukatif yang diperhatikan adalah menempatkan tingkah laku. Dapat diartikan pula bahwa hasil belajar adalah suatu

\footnotetext{
19 Ibid, 105.

${ }^{20}$ Endang Ekowati, Penelitian Tindakan Kelas, (Malang P4TK, 2007), 33.

${ }^{21}$ Ibid, 35 .

22 Muhibbin Syah, Psikologi Belajar. (Jakarta: Raja Grafindo,2003), 66.
} 
bentuk pertumbuhan atau perubahan diri seseorang yang dinyatakan dengan cara bertingkah laku baru berkat pengalaman baru".23

Hasil belajar pada hakekatnya adalah perubahan tingkah laku sebagai hasil dari proses belajar mengajar. Menurut Dimyati dan Mudjiono, hasil belajar merupakan hal yang dapat dipandang dari dua sisi yaitu sisi siswa dan dari sisi guru. Dari sisi siswa, hasil belajar merupakan tingkat perkembangan mental yang lebih baik bila dibandingkan pada saat sebelum belajar. Tingkat perkembangan mental tersebut terwujud pada jenis-jenis ranah kognitif, afektif, dan psikomotor. Sedangkan dari sisi guru, hasil belajar merupakan saat terselesaikannya bahan pelajaran. ${ }^{24}$

Menurut Bloom dalam Dimyati dan Mudjiono, aspek kognitif meliputi 6 ranah: (1) pengetahuan (knowledge); mencakup kemampuan mengingat tentang hal yang telah dipelajari dan tersimpan dalam ingatan, pengetahuan ini berkenaan dengan fakta, peristiwa, pengertian, kaidah, teori, prinsip atau metode; (2) pemahaman (comprehension); mencakup kemampuan menangkap arti dan makna hal yang dipelajari; (3) penerapan (application); mencakup kemampuan menerapkan suatu metode dan suatu kaidah untuk menghadapi masalah yang nyata dan baru; (4) analisis (analysis); mencakup kemampuan merinci suatu kesatuan ke dalam bagian-bagian sehingga struktur keseluruhan dapat dipahami dengan baik; (5) sintesis (synthesis); mencakup kemampuan membentuk satu pola baru; dan (6) evaluasi (evaluation); mencakup kemampuan membentuk pendapat tentang beberapa hal berdasarkan kriteria. ${ }^{25}$

\section{Motivasi Belajar}

Kata motif seringkali diartikan dengan istilah dorongan. Dorongan atau tenaga tersebut merupakan gerak jiwa dan jasmani untuk berbuat. Jadi motif tersebut merupakan suatu driving force yang menggerakkan manusia untuk bertingkah laku, dan di dalam perbuatanya itu mempunyai tujuan tertentu. Tidak bisa dipungkiri, setiap tindakan yang dilakukan oleh manusia selalu di mulai dengan motivasi.

Motivasi ada dua, yaitu motivasi intrinsik dan motivasi ektrinsik. Motivasi intrinsik merupakan jenis motivasi ini timbul dari dalam diri individu sendiri tanpa ada paksaan dorongan orang lain, tetapi atas dasar kemauan sendiri. Motivasi ekstrinsik merupakan jenis motivasi ini timbul sebagai akibat pengaruh dari luar individu, apakah karena adanya ajakan, suruhan, atau paksaan dari orang lain sehingga dengan keadaan demikian siswa mau melakukan sesuatu atau belajar.

Motivasi mempunyai kaitan yang erat dengan tujuan. Hasil belajar akan menjadi optimal kalau ada motivasi. Makin tepat motivasi diberikan, akan semakin berhasil pula aktivitas belajarnya. Jadi motivasi akan senantiasa menentukan intensitas belajar. Motivasi dianggap penting dalam proses belajar mengajar dilihat dari fungsi dan nilainya atau manfaatnya. Dengan demikian, motivasi akan mendorong dan mempengaruhi tingkah laku seseorang. Fungsi motivasi menurut

\footnotetext{
${ }^{23}$ Hamzah B, Uno, Perencanaan Pembelajaran, (Jakarta: Bumi Aksara, 2007), 88.

${ }^{24}$ Nana Sudjana, Penilaian Hasil Proses Belajar Mengajar. Bandung: PT. Remaja Rosdikarya, 2005), 39.

${ }^{25}$ Dimyati dan Mudjiono, Belajar dan Pembelajaran. (Jakarta: Rineka Cipta, 1999), 44.
} 
Hamalik dalam Hargono adalah sebagai berikut: (1) Mendorong timbulnya tingkah laku atau perbuatan; (2) Motivasi berfungsi sebagai pengarah; dan (3) Motivasi berfungsi sebagai penggerak, artinya menggerakkan tingkah laku seseorang. ${ }^{26}$

Cara mengakses motivasi pada siswa dapat dilakukan dengan beberapa kriteria. Menurut Keller dalam Suciati motivasi dapat diakses dari empat aspek yaitu sebagai berikut: (1) Attention (Perhatian). Perhatian peserta didik muncul karena didorong rasa ingin tahu; (2) Relevance (Relevansi). Relevansi menunjukkan adanya hubungan materi pembelajaran dengan kebutuhan dan kondisi peserta didik; (3) Confidence (Percaya diri). Merasa diri kompeten atau mampu, merupakan potensi untuk dapat berinteraksi secara positif dengan lingkungan; (4) Satisfaction (Kepuasan). Keberhasilan dalam mencapai suatu tujuan akan menghasilkan kepuasan. ${ }^{27}$

Peran guru dalam proses pembelajaran adalah untuk memberikan motivasi dari luar (motivasi ekstrinsik) sehingga dapat muncul motivasi dalam diri siswa atau dapat meningkatkan motivasi dalam diri siswa sendiri (motivasi intrinsik). Hal ini didasarkan pada pendapat bahwa motivasi dapat dirangsang oleh faktor dari luar sehingga motivasi dapat tumbuh dalam diri seseorang (Sardiman). Seorang guru dapat memberikan motivasi pada siswa. Akan tetapi besar-kecilnya motivasi yang diberikan kepada siswa tergantung pada kemampuan managerial guru dalam mengelola kelas, cara guru membuat siswa aktif, keinginan guru agar siswanya menjadi pelajar yang sukses, umpan balik yang diberikan, serta besarnya empati guru pada siswa. ${ }^{28}$

Sedangkan menurut Kamadi, motivasi belajar terbagi menjadi 4 aspek berikut: (1) Tingkah Laku; (2) Percaya Diri (Confidence); (3) Keterkaitan; dan (4) Rasa Senang. ${ }^{29}$

\section{Metode Penelitian \\ Pendekatan dan Jenis Penelitian}

Pendekatan dalam penelitian ini adalah deskriptif kualitatif karena fenomena yang diteliti memenuhi beberapa karakteristik kualitatif. Hal ini karena dalam melakukan tindakan terhadap subjek penelitian sangat diutamakan pengungkapan makna dan proses pembelajaran sebagai upaya peningkatan motivasi, aktivitas dan hasil belajar melalui pembelajaran kooperatif jigsaw melalui pendekatan kontekstual dalam siklus belajar. Data deskriptif harus dikumpulkan sebanyak-banyaknya yang dituangkan dalam bentuk laporan. Penelitian ini tidak menggunakan statitistik, walaupun tidak menolak data kuantitatif. Mementingkan proses maupun produk, sehingga dalam pelaksanaan penelitian juga memperhatikan proses. ${ }^{30}$

Jenis penelitian yang digunakan adalah Penelitian Tindakan Kelas (PTK) . Salah satu tujuan dari PTK adalah adanya perbaikan dan peningkatan profesionalisme guru dalam menangani proses belajar mengajar Penelitian ini diharapkan dapat memperbaiki dan meningkatkan motivasi, aktivitas, dan hasil

\footnotetext{
${ }^{26}$ Oemar Hamalik, Proses Belajar Mengajar. (Bandung: Bumi Aksara.2006), 138.

${ }^{27}$ Suciati dan Irawan, Teori Belajar dan Motivasi. (Jakarta: LP3M, 2001), 55.

${ }^{28}$ Sardiman. Interaksi dan Motivasi Belajar Mengajar. (Jakarta: Rajawali Pres,2005), 78.

${ }^{29}$ W. Kamadi, Model-model Pembelajaranan Inovatif. (Malang: LP3 UNM,2007), 23.

${ }^{30}$ Suharsimi Arikunto, Dasar-dasar Evaluasi Pendidikan. (Jakarta: PT. Bumi Aksara, 2007)
} 
belajar siswa. PTK ini dilaksanakan dalam dua siklus, setiap siklus terdiri dari perencanaan tindakan (planning), pelaksanaan tindakan (action), pengamatan (observation), dan refleksi (reflection).

\section{Analisis Data}

Data yang diperoleh dalam penelitian ini adalah data kualitatif dan data kuantitatif.

1. Data Kualitatif

Proses analisis data dimulai dengan menelaah seluruh data yang tersedia dari berbagai sumber, yaitu observasi, hasil tes atau ulangan harian, dan catatan lapangan. Data dalam penelitian ini akan dianalisis secara kualitatif, meliputi tiga alur yaitu reduksi data, penyajian data dan penarikan kesimpulan. Data yang di-peroleh melalui perangkat pengumpulan data akan dianalisis dan selanjutnya direduksi secara sistematis berdasarkan kelompok data, data tereduksi ini akan disajikan secara terorganisir untuk dilakukan penarikan kesimpulan.

2. Data Kuantitatif

Data kuatitatif yang dimaksud dalam penelitian ini dapat diperoleh dari besarnya motivasi belajar dan hasil belajar siswa. Adapun penjelasan lebih lanjut adalah sebagai berikut.

a. Motivasi Belajar

Motivasi belajar siswa dianalisis secara deskriptif berdasarkan deskriptor yang muncul pada lembar observasi keaktifan diskusi siswa yang meliputi keaktifan bertanya, menjawab pertanyaan, menyanggah pendapat teman, menambahkan jawaban teman, mengerjakan tugas, mengikuti pelajaran dengan senang, konsentrasi dengan tidak melakukan kegiatan lain diluar topik pelajaran. Ketentuan skor masing-masing deskriptor disajikan pada Tabel 3.3 sebagai berikut.

Tabel Penentuan Skor Masing-masing Deskriptor untuk Motivasi Belajar

\begin{tabular}{|l|c|lllll|}
\hline No. & Skor & \multicolumn{4}{|c|}{ \% deskriptor } & \\
\hline 1 & 1 & $0-20 \%$ siswa menunjukkan aktivitas seperti pada deskiptor \\
\hline 2 & 2 & $\begin{array}{l}21-40 \% \text { siswa menunjukkan aktivitas } \\
\text { deskiptor }\end{array}$ & seperti pada \\
\hline 3 & 3 & $\begin{array}{l}41-60 \% \text { siswa } \\
\text { deskiptor }\end{array}$ & menunjukkan aktivitas & seperti pada \\
\hline 4 & 4 & $\begin{array}{l}61-80 \% \text { siswa } \\
\text { deskiptor }\end{array}$ & menunjukkan aktivitas & seperti pada \\
\hline 5 & 5 & $\begin{array}{l}81-100 \% \text { siswa } \\
\text { deskiptor }\end{array}$ & menunjukkan aktivitas & seperti pada \\
\hline
\end{tabular}

b. Data Hasil Belajar Siswa

Untuk mengetahui peningkatan hasil belajar siswa ditentukan dengan ketuntasan belajar siswa secara individual dan secara klasikal. Kriteria peningkatan penguasaan minimal hasil belajar yang digunakan dalam penelitian ini adalah: 
- secara perorangan (individual), dianggap telah "tuntas belajar" apabila daya serap mencapai $70 \%$

- secara klasikal, dianggap telah "tuntas belajar" apabila mencapai 85\% dari jumlah siswa yang mencapai KKM.

\section{Hasil Penelitian}

1. Hasil Tindakan Siklus I

\section{a. Perencanaan}

Kegiatan yang dilakukan meliputi perencanaan tindakan, pelaksanaan tindakan, observasi, dan refleksi dengan perincian sebagai berikut.

Pada perencanaan tindakan siklus I, terdapat beberapa hal yang dilakukan:

1) pembuatan lembar observasi motivasi belajar siswa siklus I

2) pembuatan lembar observasi tindakan guru dalam melaksanakan pembelajaran kooperatif jigsaw dengan pendekatan kontekstual siklus I

3) pembuatan format catatan lapangan siklus I

4) pem-buatan Rencana Pelaksanaan Pembelajaran (RPP) siklus I

5) penyiapan alat dan bahan untuk proses pembelajaran siklus I

6) pembentukan kelompok belajar siswa yang heterogen dari kemampuan akademik dan jenis kelamin untuk memperlancar kegiatan pembelajaran yaitu kelompok ahli dan kelompok asal

7) pembuatan tes siklus I, soal beserta kunci jawabannya .

1. Tahap Pelaksanaan Tindakan I

Dalam tindakan siklus I yang terdiri dari 1 kali pertemuan dengan alokasi waktu 2 x 45 menit. Dalam melaksanakan strategi pembelajaran pada tahap awal guru melakukan Apersepsi yaitu memeriksa kehadiran siswa, ketertiban, kerapian kelas selama 1 menit dan memberi Motivasi terhadap siswa yaitu dengan menunjukkan gambar hubungan sosial di layar multi media proyektor di depan kelas, siswa menunjukkan nama-nama gambar hubungan sosial selama 4 menit. Kegiatan pokok/inti dilakukan 65 menit, dengan penjelasan sebagai berikut :

1. Guru menunjukkan gambar hubungan sosial di dunia di layar

2. Guru menjelaskan strategi pembelajaran dengan menggunakan model Jigsaw

3. Guru membentuk kelompok asal dan kelompok asal berjumlah 8 kelompok yang beranggotakan 4-5 siswa

4. Guru menayangkan tujuan pembelajaran yang akan dicapai

5. Guru membentuk kelompok ahli , anggota kelompok ahli yang berjumlah 4-5 siswa.

6. Siswa berkumpul dikelompok ahli untuk mendiskusikan tugas mereka

7. Siswa kembali ke kelompok asal, masing-masing anggota kelompok memaparkan hasil diskusi kelompok ahli kepada semua anggota kelompok asal sebagai nara sumber dalam kelompok.

8. Guru bersama siswa menyimpulkan hasil diskusi yang telah dibahasnya

Penutup dilakukan selama 10 menit dengan kegiatan sebagai berikut:

- Penilaian pos tes

- Siswa ditugaskan untuk mempersiapkan materi pelajaran minggu depan yaitu bentuk-bentuk hubungan sosial.

- Guru menutup pembelajaran dengan mengucapkan salam. 
Mengenai rincian tahapan pelaksanaan pembelajaran pada masingmasing tahap adalah sebagai berikut.

1. Tahap Pembagian Kelompok Asal

Pada tahap ini siswa dibentuk dalam 8 kelompok yang terdiri dari 4-5 siswa yang heterogen dalam jenis kelamin dan kemampuan akademik. Pembagian anggota kelompok yang beranggotakan 4-5 siswa bertujuan untuk memperlancar kegiatan pembelajaran.

2. Tahap Pembagian Tugas di Kelompok Asal

Pada tahap ini siswa diminta untuk membagi tugas pada masing-masing anggota kelompok dengan daftar nama anggota kelompoknya sudah ditentukan oleh guru/peneliti yang ditayangkan di layar LCD. Diharapkan setiap anggota mendapatkan bagian yang sesuai dengan kemampuan mereka berdasarkan perolehan nilai sebelum penerapan pembelajaran model jigsaw dilakukan., sehingga proses pembelajaran dapat berlangsung dengan cepat dan menyenangkan. Kemudian masing-masing anggota kelompok asal sudah ditentukan oleh guru/peneliti untuk menjadi kelompok ahli/tim ahli.

3. Tahap Diskusi Kelompok Ahli

Pada tahap ini siswa melakukan diskusi kelompok ahli sesuai dengan tugas mereka. Dalam diskusi kelompok ahli diharapkan semua anggota ikut berpartisipasi sebagai bentuk tanggung jawab mereka untuk menyampaikan hasil diskusi kelompok ahli pada kelompok asal sehingga semua anggota kelompok asal mendapatkan pengetahuan yang sama. Pada diskusi kelompok ahli ini juga dilakukan observasi sehingga semua kegiatan yang berkaitan dengan motivasi belajar siswa dapat terekam sepenuhnya oleh observer.

4. Tahap Diskusi Kelompok Asal

Pada tahap ini siswa yang telah melakukan diskusi kelompok ahli kembali ke kelompok asal untuk menyampaikan hasil diskusi yang diperoleh kepada anggota kelompok asal yang lain. Dalam diskusi kelompok asal diharapkan siswa mampu mempertanggung jawabkan tugas yang diemban yaitu mampu menyampaikan sebaik mungkin dan semaksimal mungkin hasil diskusi yang mereka peroleh dalam diskusi kelompok ahli. Sehingga semua anggota kelompok asal mendapatkan informasi pengetahuan yang sama. Pada kegiatan ini observer dan guru juga memantau setiap aktivitas belajar siswa yang dapat terekam pada lembar observasi motivasi belajar di kelompok asal.

5. Tahap Presentasi oleh Kelompok Ahli

Tahap pada presentasi oleh kelompok ahli merupakan tahap akhir pada proses pembelajaran kooperatif jigsaw. Dalam tahap ini masing-masing kelompok ahli mempresentasikan hasil diskusi mereka di depan kelas dengan kreativitas masing-masing kelompok. Pada tahap ini juga akan dilaksanakan diskusi kelas, dan guru sebagai fasilitator. Dalam kegiatan ini sangat memungkinkan sekali setiap siswa mendapatkan poin tambahan yang bersifat individu, baik dalam kegiatan bertanya, menjawab soal, ataupun menyanggah dan menambahkan jawaban teman. Pada akhir diskusi setiap kelompok ahli, guru selalu memberi penguatan pada materi yang penting. Hal ini bertujuan untuk meluruskan dan menegaskan isi materi yang dipelajari sehingga tidak ada salah paham atau apersepsi dalam memahami setiap materi. 
Dalam penelitian ini peneliti sendiri sebagai guru dan dibantu oleh satu orang observer. Pada setiap pembelajaran dilakukan observasi terhadap semua aktivitas siswa yang berhubungan dengan motivasi dan hasil belajar. Keterlaksanaan pembelajaran yang dilakukan oleh peneliti juga diperhatikan dan dinilai oleh observer dengan menggunakan lembar observasi keterlaksanaan pembelajaran.

Pada pelaksanaan postes akhir siklus I juga dilakukan observasi bagaimana pelaksanaan dan kondisi siswa saat itu. Guru juga memperingatkan siswa untuk tidak contekan dan tidak berbuat curang. Soal tes terdiri dari 5 soal pilihan ganda, pada saat potes kondisi kelas cukup tenang. Pada pelaksanaan postes akhir siklus I ditemukan 3 siswa yang mencontek. Adapun rekapitulasi hasil tes akhir siklus I dapat dilihat pada Tabel dibawah ini.

Tabel Rekapitulasi Hasil Postes Akhir Siklus I

\begin{tabular}{|c|c|c|l|}
\hline \multirow{2}{*}{$\begin{array}{c}\text { Kriteria Skor } \\
\text { Siswa }\end{array}$} & \multicolumn{2}{|c|}{ Ketuntasan } & \multirow{2}{*}{ Persentase } \\
\cline { 2 - 3 } & Tuntas & Belum tuntas & \\
\hline$\leq 50$ & - & 1 & $2,56 \%$ \\
\hline$>50$ dan $<67$ & & 3 & $7,69 \%$ \\
\hline$\geq 67$ dan $<80$ & 30 & - & $76,92 \%$ \\
\hline$\geq 80$ & 5 & - & $12,82 \%$ \\
\hline Jumlah & $\mathbf{3 5}$ & $\mathbf{4}$ & $\mathbf{1 0 0 \%}$ \\
\hline
\end{tabular}

Kelompok asal 3, 4, 5, 8 tuntas $100 \%$ dan yang belum tuntas $0 \%$, hasil ini menunjukkan bahwa kinerja kelompok asal 3, 4, 5, 8 sangat memuaskan, berarti model pembelajaran jigsaw dengan pendekatan kontekstual sangat cocok untuk diterapkan di siswa kelas X SMA Negeri 2 Sampang.

2. Tahap Observasi Tindakan I

Hasil observasi pada siklus I diperoleh temuan sebagai berikut: (1) siswa masih gaduh saat pemba-gian kelompok, (2) siswa masih bingung dengan model pembelajaran kooperatif jigsaw dengan pendekatan kontekstual sehingga guru menjelaskannya dua kali, (3) siswa takut menyampaikan pendapatnya, (4) Maka dapat disimpulkan bahwa model pembelajaraan kooperatif jigsaw merupakan hal baru bagi mereka sehingga dalam pelaksanaannya juga perlu penyesuaian siswa, (5) Guru juga harus bersabar dalam mendampingi dan membimbing siswa.

Tabel Rekapitulasi prosentase tingkat keaktifan siswa dalam diskusi pada siklus I siswa kelas X SMA Negeri 2 Sampang

\begin{tabular}{|c|c|c|c|c|c|}
\hline Kelompok & Jumlah & $\begin{array}{c}\text { Siswa } \\
\text { aktif }\end{array}$ & Prosentase & $\begin{array}{c}\text { Siswa tidak } \\
\text { aktif }\end{array}$ & Prosentase \\
\hline I & 5 & 4 & $80 \%$ & 1 & $20 \%$ \\
\hline II & 5 & 4 & $80 \%$ & 1 & $20 \%$ \\
\hline III & 5 & 3 & $60 \%$ & 2 & $40 \%$ \\
\hline IV & 5 & 4 & $80 \%$ & 1 & $20 \%$ \\
\hline V & 5 & 3 & $60 \%$ & 2 & $40 \%$ \\
\hline VI & 5 & 4 & $80 \%$ & 1 & $20 \%$ \\
\hline VII & 5 & 3 & $60 \%$ & 2 & $40 \%$ \\
\hline VIII & 4 & 4 & $100 \%$ & 0 & $20 \%$ \\
\hline
\end{tabular}




\begin{tabular}{|l|l|l|l|l|l|}
\hline & 39 & 29 & $74,36 \%$ & 10 & $25,64 \%$ \\
\hline
\end{tabular}

Berdasarkan tabel tersebut di atas dapat dikatakan bahwa tingkat keaktifan siswa dalam diskusi kelompok asal pada siklus I dengan rata-rata 74,36\% sedangkan siswa yang tidak aktif $25,64 \%$ berarti diskusi kelompok pada siklus I sudah dapat menunjang keberhasilan belajar siswa.

3. Tahap Refleksi Tindakan I

Setiap akhir siklus dilakukan refleksi tindakan yang didasarkan pada hasil observasi. Refleksi dilakukan untuk menentukan apakah pelaksanaan pembelajaran pada siklus I menunjukkan hasil yang bagus terkait dengan peningkatan motivasi dan hasil belajar siswa, juga mengetahui bila ada permasalahan atau kekurangan dalam pembelajaran, sehingga dapat menjadi perbaikan untuk siklus selanjutnya. Berdasarkan paparan data yang diperoleh dari hasil tindakan siklus I bila dibandingkan dengan data prapenelitian diketahui bahwa implementasi model pembelajaran kooperatif jigsaw dengan pendekatan kontekstual dapat meningkatkan motivasi dan hasil belajar siswa.

1. Paparan Data Siklus II

Dalam tindakan siklus II kegiatan yang dilakukan meliputi perencanaan tindakan, pelaksanaan tindakan, observasi dan refleksi dimana masing-masing kegiatan dijelaskan sebagai berikut.

1. Tahap Pelaksanaan Tindakan II

Pembelajaran siklus II dilaksanakan selama 2 x 40 menit yang dilaksanakan di SMA Negeri 2 Sampang-Sampang.

Tabel Rekapitulasi Tes Akhir Siklus II

\begin{tabular}{|c|c|c|c|}
\hline \multirow{2}{*}{$\begin{array}{l}\text { Kriteria Skor } \\
\text { Siswa }\end{array}$} & \multicolumn{2}{|c|}{ Ketuntasan } & \multirow{2}{*}{ Persentase } \\
\hline & Tuntas & Belum tuntas & \\
\hline$\leq 50$ & - & - & \\
\hline$>50$ dan $<67$ & - & 1 & $2,57 \%$ \\
\hline$\geq 67$ dan $<80$ & 14 & - & $35,90 \%$ \\
\hline$\geq 80$ & 24 & - & $61,53 \%$ \\
\hline Jumlah & 38 & 1 & $100 \%$ \\
\hline
\end{tabular}

Berdasarkan Tabel 4.5 di atas dapat diketahui hasil rekapitulasi nilai postes siklus II yang dilaksanakan pada tanggal 8 Pebruari 2011. Dari Tabel 4.5 dapat diketahui bahwa siswa yang belum tuntas dengan kriteria $\leq 50$ tidak ada, yang belum tuntas dengan kriteria $>50$ dan $<67$ sebanyak 1 siswa dengan persentase $2,57 \%$. Siswa yang tuntas dengan kriteria $\geq 67$ dan $<80$ sebanyak 14 siswa dengan persentase $35,90 \%$, dan yang tuntas dengan kriteria $\geq 80$ sebanyak 24 siswa dengan persentase $61,53 \%$. Dari hasil tes ini diketahui bahwa siswa yang belum tuntas belajar 1 orang siswa sebesar 2,57\%, dan yang tuntas 38 siswa dengan persentase $97,43 \%$.

Ketuntasan pada kelompok asal 7 sebesar $80 \%$ dan yang tidak tuntas $20 \%$, nilai ini menunjukkan bahwa kerja kelompok tersebut perlu ditingkatkan agar semua anggota kelompoknya dapat tuntas semua.

1. Hasil Observasi Tindakan II 
Tingkat Keaktifan dalam Diskusi

Hasil observasi pada siklus II diperoleh temuan sebagai berikut:(1) Ada keberanian siswa dalam menyampaikan pendapatnya, (2) Kegiatan pada kelompok dalam membahas materi sudah berjalan dengan baik, (3) siswa menyadari perlunya suatu sistem team dalam kelompok untuk dapat menyelesaikan suatu masalah.

Tabel Rekapitulasi prosentase tingkat keaktifan siswa dalam diskusi pada siklus II siswa X SMA Negeri 2 Sampang Sampang

\begin{tabular}{|c|c|c|c|c|c|}
\hline Kelompok & Jumlah & $\begin{array}{c}\text { Siswa } \\
\text { aktif }\end{array}$ & Prosentase & $\begin{array}{c}\text { Siswa } \\
\text { tidak aktif }\end{array}$ & Prosentase \\
\hline I & 5 & 4 & $80 \%$ & 1 & $20 \%$ \\
\hline II & 5 & 5 & $100 \%$ & 0 & $0,00 \%$ \\
\hline III & 5 & 4 & $80 \%$ & 1 & $20 \%$ \\
\hline IV & 5 & 4 & $80 \%$ & 1 & $20 \%$ \\
\hline V & 5 & 4 & $80 \%$ & 1 & $20 \%$ \\
\hline VI & 5 & 5 & $100 \%$ & 0 & $0,00 \%$ \\
\hline VII & 5 & 4 & $80 \%$ & 1 & $20 \%$ \\
\hline VIII & 4 & 4 & $100 \%$ & 0 & $0,00 \%$ \\
\hline & 39 & 34 & $87,18 \%$ & 5 & $12,82 \%$ \\
\hline
\end{tabular}

Berdasarkan tabel tersebut di atas dapat dikatakan bahwa tingkat keaktifan siswa dalam diskusi kelompok asal pada siklus II ada peningkatan dari $74,36 \%$ pada siklus I menjadi 87,18 \% sedangkan siswa yang tidak aktif ada penurunan dari siklus I ada 10 sisa yang tidak aktif dengan persentase $25,64 \%$ turun menjadi 5 siswa yang tidak aktif dengan persentase $12,82 \%$ berarti diskusi kelompok pada siklus II sangat t menunjang keberhasilan belajar siswa.

2. Tahap Refleksi Tindakan II

Setiap akhir siklus dilakukan refleksi tindakan yang didasarkan pada hasil observasi. Refleksi dilakukan untuk menentukan apakah pelaksanaan pembelajaran pada siklus II menunjukkan hasil yang bagus terkait dengan peningkatan motivasi dan hasil belajar siswa, juga mengetahui bila ada permasalahan atau kekurangan dalam pembelajaran, sehingga dapat menjadi perbaikan untuk pembelajaran berikutnya. Berdasarkan paparan data yang diperoleh dari hasil tindakan siklus II diketahui bahwa implementasi model pembelajaran kooperatif jigsaw dengan pendekatan kontekstual dapat meningkatkan motivasi dan hasil belajar siswa. Peningkatan motivasi dan hasil belajar dapat diketahui dengan membandingkan antara hasil observasi pembelajaran siklus I dan siklus II. Meskipun masih terdapat siswa yang belum tuntas hasil belajaranya, penelitian ini tidak lagi dilanjutkan ke siklus III. Hal ini dikarenakan sudah memenuhi kriteria peningkatan hasil belajar yang digunakan dalam penelitian ini yaitu $85 \%$ dari jumlah siswa yang mencapai KKM. 


\section{Tabel Perbandingan antara Perolehan Nilai Hasil Belajar Siswa Kelompok Asal Pada Siklus I Dengan Siklus II}

\begin{tabular}{|c|l|c|c|c|}
\hline \multirow{2}{*}{ No } & \multirow{2}{*}{ Data yang diperoleh } & \multicolumn{2}{|c|}{ Hasil Belajar } & \multirow{2}{*}{$\sum$} \\
\cline { 3 - 4 } & & Siklus I & Siklus II & Peningkatan \\
\hline 1 & Jumlah nilai & 2730 & 3020 & 290 \\
\hline 2 & Nilai Rata-rata & 70 & 77,44 & 7,44 \\
\hline 3 & $\sum$ Ketuntasan klasikal & $89,74 \%$ & $97,44 \%$ & $7,7 \%$ \\
\hline 4 & $\begin{array}{l}\sum \text { Ketidaktuntasan } \\
\text { klasikal }\end{array}$ & $10,26 \%$ & $2,56 \%$ & $7,7 \%$ \\
\hline
\end{tabular}

Berdasarkan hasil tersebut maka dapat disimpulkan bahwa penerapan model pembelajaran kooperatif jigsaw dengan pendekatan kontekstual dapat meningkatakan hasil belajar siswa, sehingga penerapan model pembelajaran efektif untuk digunakan dalam pembelajaran PKn pada kompetensi dasar Kewenangan Lembaga-lembaga Negara Menurut UUD 1945.

\section{Kesimpulan}

Berdasarkan hasil penelitian dan pembahasan sebagaimana telah diuraikan pada bab sebelumnya, dapat disimpulkan bahwa.

1. Penerapan model pembelajaran kooperatif jigsaw dengan pendekatan kontekstual dapat meningkatkan motivasi belajar siswa kelas X SMA Negeri 2 Sampang Kabupaten Sampang pada Kompetensi Dasar Kewenangan Lembagalembaga Negara Menurut UUD 1945. Terjadi peningkatan motivasi belajar siswa kelas X SMA Negeri 2 Sampang Kabupaten Sampang dari siklus I ke siklus II. Peningkatan motivasi belajar ini dikarenakan penerapan model pembelajaran kooperatif jigsaw dengan pendekatan kontekstual memberikan tanggung jawab kepada siswa atas pembelajaran untuk dirinya dan orang lain, selain itu pembelajaran kooperatif memberikan kesempatan kepada siswa untuk berkolaborasi dengan anggota kelompok, sehingga siswa termotivasi untuk belajar.

2. Penerapan model pembelajaran kooperatif jigsaw dengan pendekatan kontekstual dapat meningkatkan hasil belajar siswa kelas X SMA Negeri 2 Sampang Kabupaten Sampang pada Kompetensi Dasar Kewenangan Lembagalembaga Negara Menurut UUD 1945. Hasil belajar siswa yang diukur dengan skor rata-rata dan persentase ketuntasan belajar secara klasikal mengalami peningkatan dari siklus I dan siklus II.

3. Dengan menggunakan kontekstual melalui model pembelajaran kooperatif jigsaw memberikan kesempatan kepada siswa untuk dapat memecahkan masalah secara bekerja sama, hal ini berdampak terhadap adanya ide-ide baru untuk menemukan yang baru.

Kemampuan guru dalam menggunakan pendekatan kontekstual melalui model pembelajaran jigsaw cukup berhasil, hal ini dapat dilihat dari hasil evaluasi diperoleh temuan (a) dari 39 siswa peserta tes pada siklus I diperoleh total nilai 2730, sedangkan pada siklus II diperoleh nilai 3020, hal ini berarti terjadi kenaikan 
sebesar 290 poin; (b) nilai rata-rata siklus I adalah 70,00 sedangkan pada siklus II adalah 77,44 , hal ini berarti terjadi kenaikan sebanyak 7,44 poin. Untuk ketuntasan klasikal pada siklus I mencapai $89,74 \%$, dan mengalami peningkatan menjadi 97,44 berarti meningkat $7,7 \%$, hal tersebut tentunya juga akan mempengaruhi terhadap siswa yang belum tuntas secara klasikal siswa yang belum tuntas pada siklus I adalah 10,26 menurun pada siklus II siswa yang belum tuntas tingga 2,56\%. Hal tersebut dapat disimpulkan bahwa penerapan model pembelajaran kooperatif jigsaw dengan pendekatan kontektual dapat meningkatkan hasil belajar siswa, sehingga penerapan model pembelajaran sangat efektif untuk digunakan dalam pembelajaran PKN pada kompetensi dasar Kewenangan Lembaga-lembaga Negara Menurut UUD 1945.

\section{Daftar Pustaka}

Arends, I. Richard. Model-model Pembelajaran Kooperatif. (Yogyakarta: Pustaka Belajar, 2007).

Arikunto, S. Dasar-dasar Evaluasi Pendidikan. (Jakarta: PT. Bumi Aksara, 2007).

Dasna, I. Wayan dan Sutrisno. Model-model Pembelajaran Konstruktivistik dalam Pengajaran Sains/Kimia. (Malang: Universitas Negeri Malang, 2006).

Dimyati dan Mudjiono. Belajar dan Pembelajaran. (Jakarta: Rineka Cipta, 1999).

Hamalik, Oemar. Proses Belajar Mengajar. (Bandung: Bumi Aksara, 2006).

Ibrahim, M. dan Nur, M. Pembelajaran Berdasarkan Masalah. (Surabaya: Universitas Negeri Surabaya Press, 2000).

Kamadi, W. Model-model Pembelajaranan Inovatif. (Malang: Lembaga Pengembangan Pendidikan dan Pembelajaran Universitas Negeri Malang, 2007).

Lie, A. Mempraktekkan Cooperative Learning di Ruang-ruang Kelas. (Jakarta: PT. Gramedia, 2007).

Nurhadi dkk. Pembelajaran Kontekstual dan Penerapannya dalam KBK. (Malang: Universitas Negeri Malang, 2004).

Sanjaya, Wina. Strategi Pembelajaran Berorientasi Standar Proses Pendidikan. (Jakarta: Kencana Prenada Media Group, 2006).

Sardiman. Interaksi dan Motivasi Belajar Mengajar. (Jakarta: Rajawali Pres, 2005).

Suciati dan Irawan, P. Teori Belajar dan Motivasi. (Jakarta: Pusat antar Universitas untuk Peningkatan dan Pengembangan Aktivitas Intruksional., 2001).

Sudjana, Nana, Penilaian Hasil Proses Belajar Mengajar. (Bandung: PT. Remaja Rosdikarya, 2005).

Syah, Muhibbin, Psikologi Pendidikan dengan Pendekatan Baru. (Bandung: Rosdakarya, 2007).

Syah, Muhibbin, Psikologi Belajar. (Jakarta: PT Raja Grafindo, 2005) 